\title{
Spatial segregation between Chalceus guaporensis and Chalceus epakros (Osteichthyes: Characiformes) in the Madeira River, Amazon Basin
}

\author{
Gislene TORRENTE-VILARA ${ }^{1,2,4 *}$, Ariana CELLA-RIBEIRO ${ }^{3,4}$, Marília HAUSER $^{3,4}$, Cristhiana RÖPKE ${ }^{5}$, \\ Maria Helena FREITAS 5 , Carolina Rodrigues da Costa DORIA ${ }^{3,4}$, Jansen ZUANON ${ }^{5}$ \\ Universidade Federal de São Paulo, Departamento de Ciências do Mar, Campus Baixada Santista. Rua Doutor Carvalho de Mendonça, 144, Encruzilhada, 11070-100, \\ Santos, SP, Brazil. \\ Universidade Federal do Amazonas, Av. General Rodrigo Octavio Jordão, 3000, Manaus, AM, Brazil \\ Universidade Federal de Rondônia, BR 364, km 9.5, Zona Rural, 76815-800, Porto Velho, RO, Brazil \\ ${ }^{4}$ Universidade Federal de Rondônia/Pós-graduação Rede de Biodiversidade e Biotecnologia da Amazônia Legal (Bionorte), BR 364, km 5.5, Zona Rural, 76815-800, Porto \\ Velho, RO, Brazil \\ Instituto Nacional de Pesquisas da Amazônia, Coordenação de Biodiversidade, Avenida André Araújo, 2936, Petrópolis, 69067-375, Manaus, AM, Brazil \\ * Corresponding author: gtvilara@gmail.com
}

\begin{abstract}
Chalceus guaporensis is an endemic fish to the upper Madeira River whereas C. epakros is widespread in many rivers of the central and lower portions of the Amazon Basin, middle and upper Orinoco River Basin, the Essequibo River in Guyana and in the Nanay River in northern Peru. According to literature, both species do not occur in syntopy. We carried out ichthyological surveys along the Madeira River Basin and its rapids, and data on abundance, diet and habitat use were obtained for both species. Chalceus guaporensis and $C$. epakros are morphologically similar, occupying floodplain habitats and exploiting similar food resources. The former predominated upstream from the Jirau Fall, whereas the latter had most of its abundance bellow the last fall of the Madeira River; both species cooccurred along part of the rapids stretch and in the Machado River, but with strongly uneven abundances. This pattern may have developed in the past by speciation regarding the presence of the falls, while co-occurrence of the two species seems to be regulated by competitive interactions or maintained by slight differences in environmental requirements nowadays. The recent disruption of the Madeira River by two run-of-river dams built in cascade submerged a large portion of the rapids stretch and substituted it by semi-lenthic habitats created by the dam reservoirs, together with the construction of a fish passage. These environmental changes may allow the invasion of the upper reaches of the Madeira River by C. epakros, and disturb the population of endemic C. guaporensis.
\end{abstract}

KEYWORDS: Alestidae; coexistence; biology; geographical barrier; muddy water

\section{Segregação espacial entre Chalceus guaporensis e Chalceus epakros (Osteichthyes: Characiformes) no rio Madeira, Bacia Amazônica}

\section{RESUMO}

Chalceus guaporensis é descrita como uma espécie endêmica do alto rio Madeira, enquanto C. epakros está amplamente distribuída em rios das porçóes central e inferior da bacia Amazônica, no médio e alto rio Orinoco, e nos rios Essequibo, na Guiana, e Nanay, no norte do Peru. A literatura náo registra essas espécies como sintópicas. Expediçóes ictiológicas realizadas ao longo do rio Madeira e suas corredeiras nos deram a oportunidade de registrar a presença, abundância, habitat e dieta utilizadas por essas espécies. Chalceus guaporensis e C. epakros são muito similares morfologicamente, ocupam habitats inundáveis e apresentam espectro alimentar semelhante. A primeira espécie predominou a montante da cachoeira Jirau, enquanto que a segunda teve a maior parte de sua abundância registrada à jusante das cachoeiras do rio Madeira. Ambas espécies coocorreram ao longo de parte do trecho de corredeiras e no rio Machado, mas com abundâncias muito desiguais. Esse padrão pode ter se desenvolvido no passado, por especiação, em função da presença das corredeiras, enquanto a coocorrência das duas espécies parece ser regulada por interaçóes competitivas ou mantida por diferenças sutis em requisitos ecológicos no tempo atual. O recente barramento do rio Madeira por duas hidrelétricas construídas em cascata submergiu uma grande porção do trecho de corredeiras e o substituiu por habitats semilênticos, criados pelos reservatórios das hidrelétricas a fio d'água, juntamente com a construção de uma passagem para peixes. Essas alteraçóes ambientais podem permitir que C. epakros invada o trecho superior da bacia do rio Madeira, com possíveis impactos negativos sobre a população da espécie endêmica C. guaporensis.

PALAVRAS-CHAVE: Alestidae; coexistência; biologia; barreira geográfica; água branca 


\section{INTRODUCTION}

Information on the spatial distribution and ecological interactions among species are fundamental to understanding the factors that allow coexistence in biological communities (Mooney et al. 2008). In this context, sympatric congeneric species may present unique research opportunities (and challenges) to explain the mechanisms responsible for species coexistence (Helmus et al. 2007). Pairs of sympatric congeneric species, especially sister species, share similar phenotypic and ecological traits, with the possible exception of those biological characteristics that have diverged as a function of competition (Mooney et al. 2008). When two species compete for the same resource, the one with a slight advantage will out-compete the other, which is known as the competitive exclusion principle while when no extinction occurs, it is due to adaptation to slightly different niches (Capitán et al. 2015). Coexistence theory might guide a general understanding of when and how biotic interactions impact the limits of a species' range (Godsoe et al. 2017). However, an unresolved question refers to the spatial scales at which species coexist, conceptualizing the outcome of a geographic-scale coexistence problem (Hart et al. 2017).

Alestidae, a predominantly African representative of the Characiformes, includes 116 valid species (Eschmeyer et al. 2017) of which Chalceus (with five species) is the only genus present in the Neotropics, occurring in the Amazon, Orinoco and Essequibo river basins (Zanata and Toledo-Piza 2004; but see Oliveira et al. 2011 for a different phylogenetic hypothesis for Chalceus). Four species of Chalceus were recorded in the Madeira River Basin, Chalceus guaporensis Zanata and Toledo-Piza 2004, Chalceus epakros Zanata and Toledo-Piza 2004, Chalceus erythrurus (Cope 1870) and Chalceus macrolepidotus Cuvier 1818, but the last two species are represented by a single record each (Zanata and ToledoPiza 2004; Zanata 2013). Chalceus guaporensis is considered endemic to the Guaporé, Mamoré, Madre de Dios and upper Madeira rivers, and can be distinguished from congeneric species mainly by the presence of seven (vs. eight) branched pelvic-fin rays. Chalceus epakros has a much wider distribution throughout the central and lower portions of the Amazon Basin (including the lower course of the Madeira River), middle and upper Orinoco River Basin, the Essequibo River in Guyana and the Nanay River in Peru (Zanata and Toledo-Piza 2004; see www.gbif.org for occurrence points of Chalceus species). Zanata and Toledo-Piza (2004) also suggested that the natural limit of the distribution of these species in the Madeira River would be the Santo Antônio Fall, which was recently obliterated by the construction of the Santo Antônio run-of-river dam. However, the Santo Antônio Fall was constituted by a low-slope stretch of rapids that may not necessarily have acted as an absolute barrier to Chalceus species distribution (Cella-Ribeiro et al. 2013). Moreover, the Teotônio and Jirau falls, located a few kilometers upstream, have been demonstrated to be stronger barriers to several fish species (Torrente-Vilara et al. 2011).
The strong morphological similarity of these two species of Chalceus indicates similar ecological characteristics (cf. Peterson 1999), thus their apparently disjointed distributions could be the result of competitive exclusion (Anderson et al. 2002) or a result of an allopatric speciation due to ecological barriers. In this study we hypothesize that the distribution ranges of $C$. guaporensis and C. epakros result mostly from historical factors linked to the geographic barrier represented by the downstreammost falls of Madeira River (Teotônio and Santo Antônio falls). If this holds true, then both species should have sharply disjunctive distributions, with a (possible) narrow contact zone in the rapids where the abundances of the species should be strongly unbalanced (C. guaporensis dominating upstream, and C. epakros downstream of the falls). Alternatively, if the distributions observed are not completely disjunct, they may be a result of ecological segregation by limiting similarity, with both species co-occurring along a wide contact zone, with differences in local relative abundances not being geographically structured. We also describe ecological aspects of reproduction, feeding, and habitat used by adults of C. guaporensis and C. epakros, comparing these aspects between species whenever possible. Our results highlight biological aspects of both species and may be especially important for the conservation of the endemic $C$. guaporensis in the Madeira River Basin, recently subjected to the impacts of the Santo Antônio and Jirau run-of-river dams.

\section{MATERIAL AND METHODS}

\section{Study area}

The Madeira River is a muddy water river which transports a huge amount of suspended sediments (Sioli 1968), with a mean annual discharge of $31,704 \mathrm{~m}^{3} \cdot \mathrm{s}^{-1}$ that corresponds to $-15 \%$ of the Amazon River mean discharge (Siqueira-Júnior et al. 2015). However, all of its tributaries in the study area have clear to blackish waters that are pushed upstream by Madeira River muddy waters during the flood season, which usually lasts from October to April. Rock outcrops are present in the upper portion of the river, with large boulders emerging and forming a series of rapids. The most important geographical features along the upper Madeira River were the Teotônio and Jirau falls, which represented natural limits for frogs (Simóes et al. 2008; 2010), alligators (Hrbek et al. 2008), and acted as an environmental filter for several fish species (Torrente-Vilara et al. 2011). Also, Teotônio and Jirau falls were considered to have driven allopatric speciation for frogs (Simóes et al. 2010), population structure for turtles (Santos et al. 2016) and sardines (Queiroz et al. 2017), and hybrid zones for frogs (Simóes et al. 2012) and dolphins (Gravena et al. 2015). Both falls, along with other rapids in the upper Madeira River, were flooded in 2011 by the Santo Antônio and Jirau run-of-river dams built at a $110-\mathrm{km}$ interval over the Santo Antônio and the upriver Caldeirão rapids, respectively. 


\section{Fish sampling}

Sixteen sampling sites were established at the mouth of the main tributaries of a section about $1500 \mathrm{~km}$ between the cities of Costa Marques, on the upriver major clear water tributary Guaporé River at the Brazil-Bolivia border, and Nova Olinda do Norte, close to the mouth of the Madeira River into the Amazon River. Six sites were upriver from the Jirau Fall, two between the Jirau and Teotônio falls, one between the Teotônio and Santo Antônio falls, and seven below Santo Antônio (Figure 1). Details of sampling sites and Madeira River rapids are available in Queiroz et al. (2013) and Cella-Ribeiro et al. (2016). All tributaries were characterized as clear-black water with $\mathrm{pH}$ varying from 4.8 and 6.6 (Torrente-Vilara et al. 2011). Fish were sampled monthly, from April 2009 to March 2010, and bimonthly from April 2010 to February 2013. A set of 13 gill nets with 30-200 mm mesh size (measured between opposite knots) was exposed in each site for $24 \mathrm{~h}$ on each sampling event.

\section{Biological data}

After each sampling occasion, fish were sorted and Chalceus specimens were separated, identified, counted, and individually measured (standard length, SL, in $\mathrm{cm}$ ). An abdominal incision exposed the gonads for macroscopic determination of sex and gonadal maturation (immature, developing, mature, spawning, regressing and regenerating; Núnez and Duponchelle 2009). The stomach repletion index (SRI) was determined based on the space filled by food in the stomach (Hahn et al. 1999) where: 0 (empty), 1 (up to 25\%), 2 (between 25 and 75\%), and 3 (75\% to completely full). Voucher specimens were preserved in $10 \%$ formalin, subsequently transferred to $70 \%$ ethanol and deposited in the Fish Collection of the Universidade Federal de Rondônia under acronym UFRO-I. All data were collected by the Laboratório de Ictiologia e Pesca (LIP) of the Universidade Federal de Rondônia (UNIR) at Porto Velho, Rondônia state, Brazil, under the Santo Antônio Energia (SAE) and Energia Sustentável do Brasil (ESBR) Fish Conservation Programs (Permit \#51/09 from Instituto Brasileiro do Meio Ambiente e Recursos Naturais Renováveis - IBAMA).

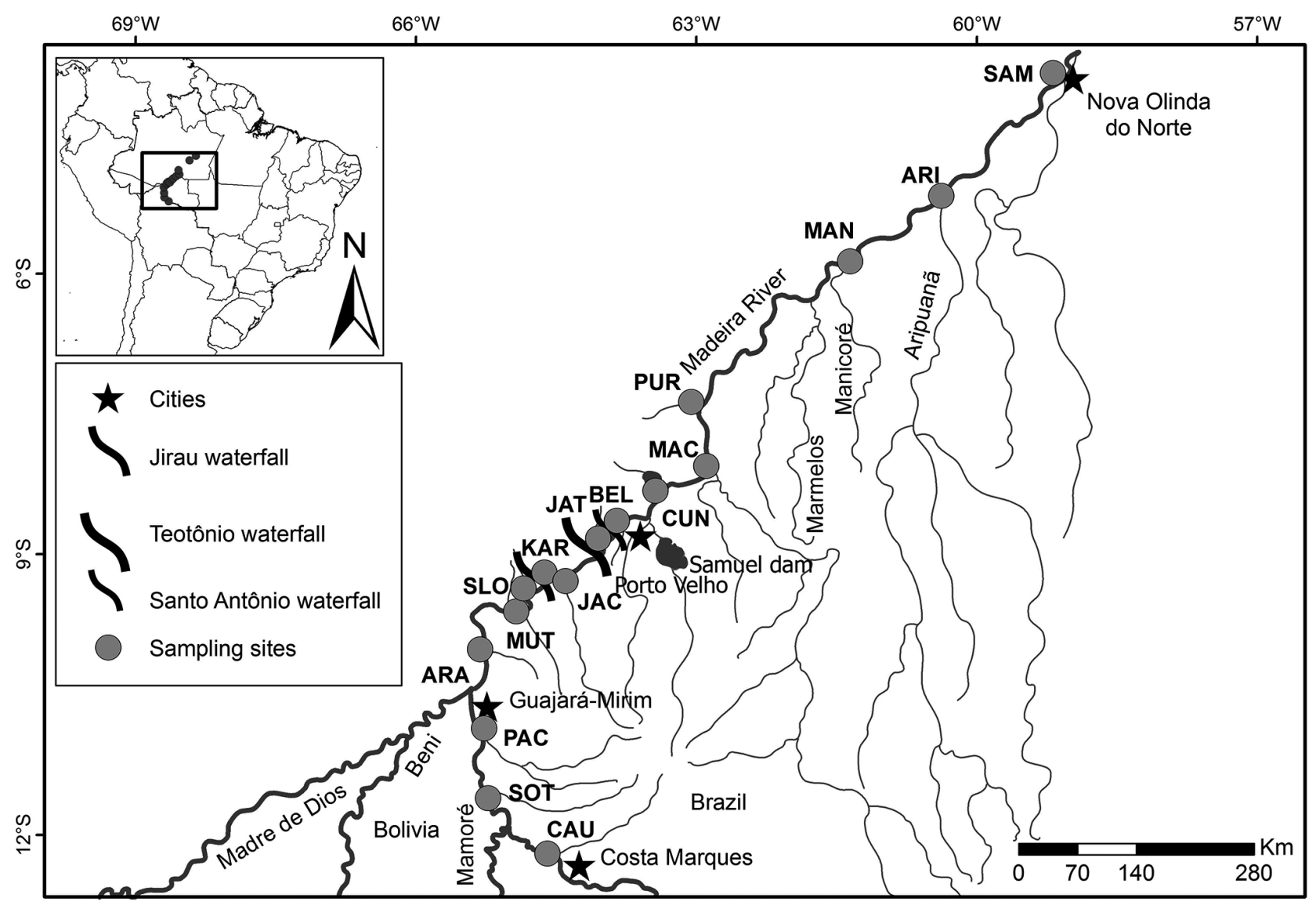

Figure 1. Study area and location of sampling sites. CAU: Cautário River, SOT: Sotério River, PAC: Pacaás River, ARA: Araras stream, MUT: Mutum-Paraná River, SLO: São Lourenço River, KAR: Karipunas stream, JAC: Jaciparaná River, JAT: Jatuarana stream, BEL: Belmont, CUN: Cuniã Lake, MAC: Machado River, PUR: Puruzinho Lake, MAN: Manicoré River, ARI: Aripuanã River, SAM: Sampaio Lake. Falls indicated from upstream to downstream in the Madeira River are Jirau, Teotônio and Santo Antônio. The size of the fall symbol represents the degree of barrier importance. 


\section{Data analysis}

We tested the hypothesis that Teotônio Fall constitutes the distributional limit for the two Chalceus species by pooling abundance data of each species and running a binomial regression analysis (general linear models_-GLM with a logit link) with presence/absence data ( 1 and 0$)$ as a function of the distance from the Teotônio Fall. Parameter estimates were used to predict probability of occurrence of species along the distance axis (distance from Teotônio Fall). The analyses were carried out in the $\mathrm{R}$ software (R Core Team 2014), using $g l m$ function from MASS 1.3 (Venables \& Ripley, 2001) and graphics were made with the ggplot2 package (Wickham, 2009).

The temporal distribution of relative frequencies for gonadal development phases was used to infer the spawning period. The size at first gonadal maturation was estimated by fitting the size distribution of adult individuals in classes of 2 $\mathrm{cm}$ SL intervals in a logistic regression function (Duponchelle et al. 2007). The lengths when $50 \%$ and $100 \%$ of the population reaches maturity $\left(\mathrm{L}_{50}\right.$ and $\mathrm{L}_{100}$, respectively) were established for grouped males and females due to the low number of immature specimens.

The relative contribution of the food items for the diet of both Chalceus species was analyzed by frequency of occurrence $(\mathrm{FO} \%=$ number of times that a food type occurred in the stomach contents in relation to the total number of stomachs with food), and relative volume (VO\% = ratio between the estimated volume of each food item and the total volume of food in the stomachs; cf. Hyslop 1980). A visual estimate of the relative volume was done for each item in the stomach content (Hahn et al. 1999). Since we considered each stomach as having $100 \%$ of the total volume, these values were multiplied by the stomach fullness index (see above) to correct its relative value. Both methods (FO and VO) were combined in the alimentary index (IAi; Kawakami and Vazzoler 1980).
Food items were identified to the most precise taxonomic level possible, mostly to order or family for invertebrates.

\section{RESULTS}

A total of 330 specimens of Chalceus guaporensis and 57 of $C$. epakros were captured. Both species were most abundant in the largest tributaries of the Madeira River in the study area. About $30 \%$ of C. guaporensis occurred in the Jaciparaná River $(\mathrm{N}=98)$, the largest tributary in the upper Madeira rapids section, and $25 \%$ in the São Lourenço stream $(\mathrm{N}=76)$ above Jirau (Figure 2). Almost $60 \%$ of the total abundance of C. epakros occurred in the Machado River $(\mathrm{N}=33)$, a major tributary below Santo Antônio (Figure 1). Chalceus specimens were captured in 362 out of 398 samples obtained during the study period; however, Chalceus guaporensis and C. epakros were collected together in only four samplings, with varying proportions: twice in Machado River (1:1 and 1:5) and once in Sampaio Lake (1:2), below Santo Antônio Fall, and once in the Karipunas stream (1:2) above Teotônio Fall. The three sampling sites where both Chalceus species co-ocurred are located downstream from the Jirau Fall (Figures 1 and 2). Chalceus epakros abundance $(\mathrm{N}=57)$ was higher downstream from the Teotônio Fall, on the sedimentary portion of the Madeira River (98\% of total abundance, Figure 2). On the other hand, Chalceus guaporensis $(\mathrm{N}=330)$ predominated upstream from the Teotônio Fall (68\% of total abundance, Figure 2). Therefore, the rapids stretch and the Machado River formed the main contact zones for populations of C. guaporensis and C. epakros (Figure 2).

The binomial GLM analysis indicated that the probability of occurrence of both species showed a significant association with the distance from the Teotônio Fall $(\mathrm{P}<0.001$; Figure 3$)$. Chalceus guaporensis had a high overall probability of occurrence along the sampling sites, with a maximum of 0.99 at the most upstream site, decreasing in downstream direction to 0.29 (mean $=0.87 \pm$ 0.20 DP). Chalceus epakros, however, had almost half the overall probability of occurrence of $C$. guaporensis (mean $=0.44 \pm 0.39$

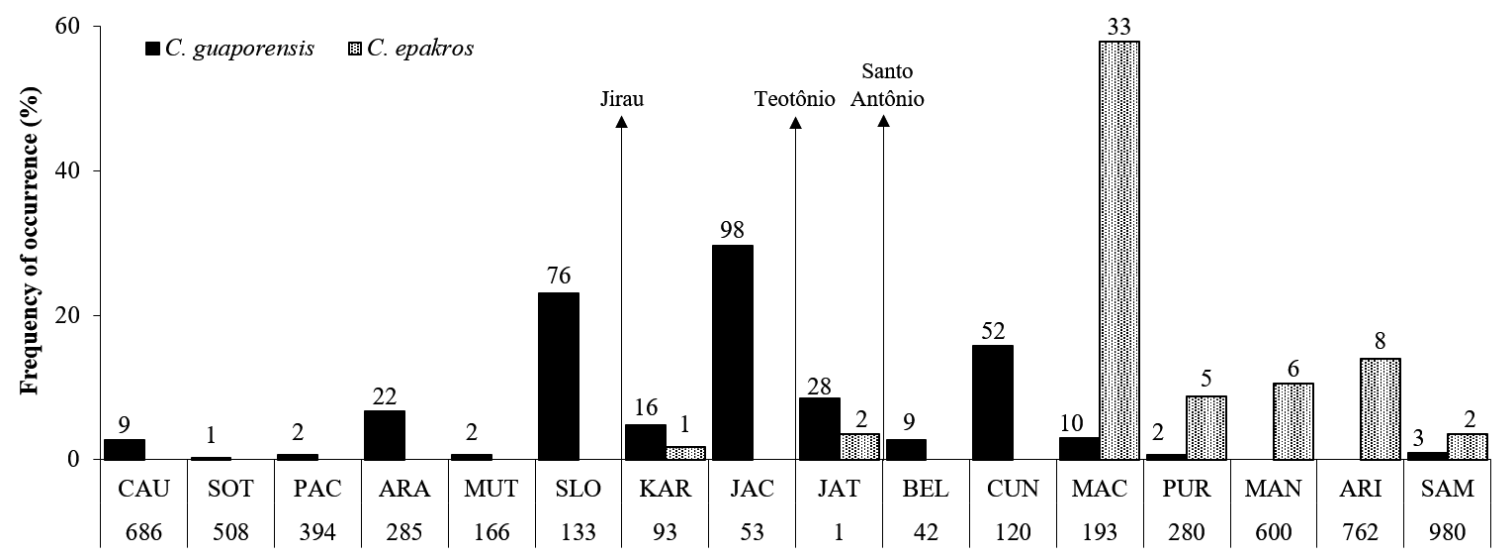

Figure 2. Frequency of occurrence of Chalceus guaporensis and C. epakros in Madeira River tributaries between 2009 and 2013, and the position of the Jirau, Teotônio and Santo Antônio falls. The number below the site abbreviation indicates the distance $(\mathrm{km})$ from the Teotônio Fall. The number above the bar indicates the absolute abundance of each species at each sampling site. 


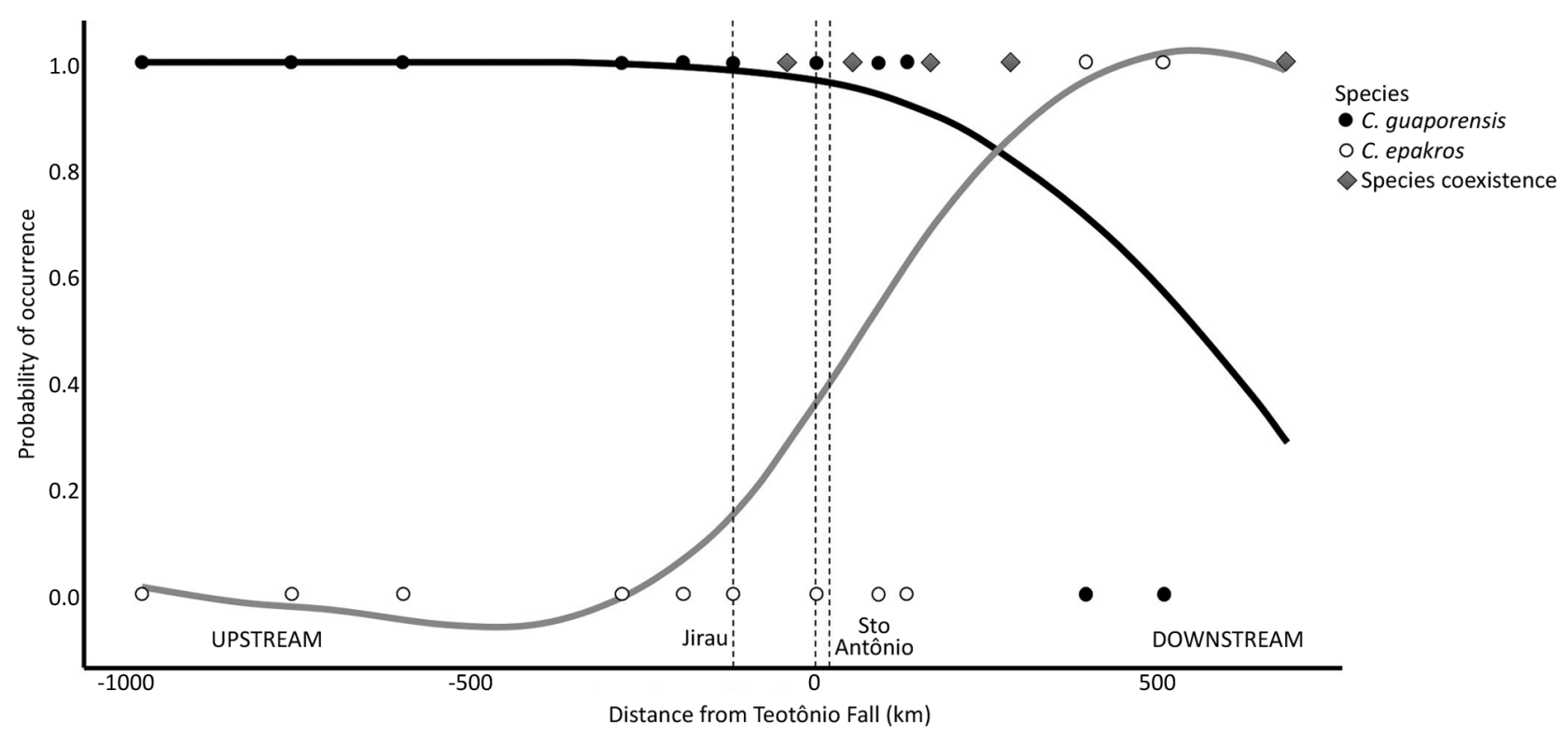

Figure 3. Observed records (presence/absence data; individual symbols) and predicted probabilities of occurrence (smoothed lines) for Chalceus guaporensis (black symbols/black line) and C. epakros (white symbols/grey line) along the Madeira River. Predicted values were based on a binomial GLM model with distance from the Teotônio Fall as a fixed predictor. Grey diamonds represent sites where the two species co-occurred. The X axis indicates distances upstream (negative values) and downstream (positive values) from the Teotônio Fall (position zero on the axis) representing the river flow from west to east. The dashed lines mark the position of the Teotônio, Jirau falls (upstream) and Santo Antônio Fall (downstream) on the relative distance axis. Zero and 1 along the Y axis represent, respectively, absence and presence of the species.

DP). The probability of occurrence of C. epakros was maximum $(0.99)$ at the most downstream site, and reached almost zero above the Jirau Fall.

The size of the collected specimens of $C$. guaporensis ranged between 2.0 and $18.4 \mathrm{~cm} \mathrm{SL}\left(\mathrm{SL}_{\text {cass mode }}=14.2 \mathrm{~cm}\right.$, Table 1$)$, while for C. epakros it varied between 9.5 and $15.1 \mathrm{~cm} \mathrm{SL}\left(\mathrm{SL}_{\text {class mode }}=\right.$ $10.5 \mathrm{~cm}$, Table 1). Most specimens of C. guaporensis were adults, with only a few immature fish $\left(\mathrm{N}_{\text {immature }}=38\right)$. The smallest mature C. guaporensis measured $10.7 \mathrm{~cm}$ SL among males, and 15.7 $\mathrm{cm}$ among females. For both genders combined the estimated $\mathrm{L}_{50}$ was $9.9 \mathrm{~cm} \mathrm{SL}$, and all individuals reached maturity at 13.3 $\mathrm{cm} \mathrm{SL}\left(\mathrm{L}_{100}\right)$. Ripe or spawning females of $C$. guaporensis $(\mathrm{N}=$ 6) were found only in December in the São Lourenço River, during the rising water period. However, the only reproducing male was registered at the Karipunas stream, separated from the São Lourenço River by the Jirau Fall. Ripe and ready to reproduce females and males of $C$. epakros were not captured during our study.

The diet of $C$. guaporensis ( $\mathrm{N}=35$ specimens with food) was composed mainly of allochthonous invertebrates (IAi $=60.5 \%$ ), mostly ants (Formicidae; 51.6\%) (Table 2). Authochtonous items (aquatic insects; IAi=18.3\%) were mainly composed by Lepidoptera larvae (12.4\%). Only four specimens of C. epakros had food in their stomachs, with $61 \%$ of the diet composed of allochthonous food items, mostly Hymenoptera (36.9\%) and Blattodea (Kalotermitidae; 24\%).
Table 1. Total abundance and body size parameters of Chalceus guaporensis and C. epakros captured in the Madeira River between 2009 and 2013. SL = standard length; $L_{50^{\prime}} L_{100}=$ lengths when $50 \%$ and $100 \%$ of the population reach maturity, respectively; $L W R=$ length-weight relationship. Numbers are individual measurements or the mean $\pm S D$, and the range (minimum-maximum) (in $\mathrm{cm}$ ). $\min \mathrm{SL}=$ smallest body size for that category. LWR values are from Cella-Ribeiro et al. (2015).

\begin{tabular}{lcc}
\hline & Chalceus guaporensis & Chalceus epakros \\
\hline Abundance & 330 & 57 \\
\hline SL (overall) & $12.1 \pm 2.5(2.0-18.4)$ & $10.9 \pm 1.4(9.5-15.1)$ \\
\hline SL (females) & $13.2 \pm 2.2(9.1-18.4)$ & $\begin{array}{c}11.8 \pm 1.7(10.0- \\
14.2)\end{array}$ \\
\hline SL (males) & $13.1 \pm 1.6(9.6-15.7)$ & $11.4 \pm 1.7(10.1-$ \\
min SL mature female & 13.6 & --- \\
\hline min SL mature male & 10.7 & --- \\
\hline$S L$ immature females & $9.5,10.0,10.3,11.2$ & --- \\
\hline SL immatures (not sexed) & $(2.0-11.1)$ & --- \\
\hline$L_{50}$ & 9.9 & --- \\
\hline$L_{100}$ & 13.5 & $W t=0.0162 L S^{3.0929}$ \\
\hline LWR & $W t=0.0109 L^{3.2669}$ & \\
\hline
\end{tabular}


Table 2. Alimentary Index (IAi) of major food items in the diet of Chalceus guaporensis $(n=35)$ and C. epakros $(n=4)$ captured in the Madeira River between 2009 and 2013, grouped by food source. ${ }^{*}=$ refers to the total IAi \% of each major taxonomic group (adapted from Cella-Ribeiro et al. 2016).

\begin{tabular}{|c|c|c|}
\hline Food items & $\begin{array}{l}\text { Chalceus } \\
\text { guaporensis }\end{array}$ & $\begin{array}{l}\text { Chalceus } \\
\text { epakros }\end{array}$ \\
\hline \multicolumn{3}{|l|}{ Allocthonous source } \\
\hline Phylum Arthropoda & $60.5^{*}$ & $61^{*}$ \\
\hline Class Arachnida (spiders) & 2.2 & \\
\hline Class Insecta & $58.3^{*}$ & \\
\hline Order Coleoptera (beetles) & 0.3 & \\
\hline Order Hymenoptera & $52.4^{*}$ & $36.9^{*}$ \\
\hline Family Formicidae (ants) & 51.6 & 6.8 \\
\hline Family Vespoidae (wasps) & & 6.0 \\
\hline non identified hymenopterans & 0.8 & 24.1 \\
\hline \multicolumn{3}{|l|}{ Order Blattodea } \\
\hline Family Termitidae (termites) & 0.2 & \\
\hline Family Kalotermitidae (termites) & & 24.1 \\
\hline Order Orthoptera (crickets) & 5.4 & \\
\hline \multicolumn{3}{|l|}{ Autocthonous source } \\
\hline Class Insecta & $18.3^{*}$ & $39.0^{*}$ \\
\hline Order Hemiptera (aquatic bedbugs) & 4.9 & 7.5 \\
\hline Order Lepidoptera (butterflies) (larvae) & 12.4 & \\
\hline Order Odonata (dragonflies) (larvae) & 1.0 & \\
\hline non-identified insects & & 31.5 \\
\hline \multicolumn{3}{|l|}{ Unidentified source } \\
\hline Plants & $11.0^{*}$ & \\
\hline Other material & $10.3^{*}$ & \\
\hline
\end{tabular}

\section{DISCUSSION}

One of the main questions concerning species distribution patterns refers to which sites should be sampled to provide an accurate representation of their distribution among habitat patches throughout the landscape (Thomas and Kunin 1999). This is often estimated by the species' presence or absence in the sampling sites (Tischendorf and Fahrig 2000; Tremlová and Münzbergová 2007). Our study showed a pattern of partial spatial segregation of the two Chalceus species along the Madeira River. Chalceus guaporensis were hypothesized by Zanata and Toledo-Piza (2004) to be endemic to the upper Madeira River and limited downstream by the Santo Antônio Fall. Indeed, $C$. guaporensis predominated in the tributaries along the rapids stretch upstream from that fall. However, several specimens of C. guaporensis were collected downstream from the falls, therefore expanding its known distribution in the Madeira River Basin. One possible explanation to the presence of $C$. guaporensis downstream from the rapids could be related to a very recent range expansion, or, alternatively, to an intermittent presence related to temporally favorable environmental conditions. The hydrologic year of 2008-
2009 had higher discharges than the average expected for the Madeira River Basin, according to the levels registered at Guajará-Mirim (Ovando et al. 2016). Since the flood season regulates fish reproduction (Lowe-McConnell 1987; Araújo-Lima and Oliveira 1998), extreme flood events might facilitate larvae drift downstream and surpassing the falls, creating opportunities to increased species dispersal and colonization of the floodplain bellow the rapids. In this sense, the river stretch downstream from the rapids could be a demographic sink for C. guaporensis related to differences in the intrinsic growth rate or in the strength of the biotic interactions between the sister species (q.v. Godsoe et al. 2017), which remains to be investigated. The supposed absence of $C$. guaporensis downstream the rapids stretch proposed by Zanata and Toledo-Piza (2004) possibly reflected only a detection failure of the species resulting from its low local abundance, combined with a historical undersampling of that portion of the Madeira River.

Chalceus epakros was most abundant in the sedimentary portion of the Madeira River Basin, especially in the Machado River, and no specimens were collected upstream from the Jirau Fall. This apparent geographical limitation is surprising, considering the broad geographic distribution of C. epakros in the Amazon Basin (Zanata and ToledoPiza 2004), which contrasts to the restricted distribution and endemicity of C. guaporensis in the upper Madeira River Basin. The phylogenetic proximity and high overall morphological similarity between the two Chalceus species point out to similar ecological requirements, which could be expected by the niche conservatism hypothesis (Peterson 1999). However, the two species were rarely collected together in the same sample (4 out of 364), despite occupying apparently very similar environments (forested stretches of large clear and blackish water streams and rivers, with well oxygenated waters, where they occupy the upper layer of the water column and forage for invertebrates; Planquette et al. 1996; Zanata and Toledo-Piza 2004; Zuanon and Ferreira 2008; Torrente-Vilara et al. 2011; our personal field observations). This pattern of distribution may have developed in the past by speciation regarding the presence of the falls (Dias et al. 2013) and maintained in the present by ecological factors. Two hypotheses could explain this pattern of co-occurrence: i) slightly different environmental requirements among species (e.g. Estevo et al. 2017), with C. guaporensis having greater ability to cope with longitudinal changes in environmental conditions than $C$. epakros; or ii) competitive interactions between both Chalceus species, resulting in the observed slight overlap (with uneven abundances) at their limits of distribution (Brown and Wilson 1956; Hutchinson 1959; Davies et al. 2007).

Chalceus guaporensis had a higher overall abundance, suggesting that this species could be best adapted to the habitats found at tributaries along the rapids stretch, where 
seasonal flooding dynamics is temporally more variable and strongly responds to local rainfall. On the other hand, C. epakros would be better fitted for the conditions that predominate in the sedimentary plains downstream in the Madeira Basin, where the connectedness to the main Amazon lowlands results in a temporal dynamic that follows a more regular and predictable annual flood pulse (Junk et al. 1989). However, C. epakros occurs in a much wider area in the Amazon Basin, which embraces an ample range of environmental conditions that include similar habitats to those occupied by C. guaporensis in the upper stretches of the Madeira River.

Despite the seemingly absence of conspicuous differences in the habitats occupied by the two Chalceus species upstream and downstream from the main falls in the Madeira River, the possible effect of environmental factors influencing their distribution along the river cannot be ruled out. Environmental differences (usually considered environmental filters) might act in conjunction with competitive interactions in determining patterns of species co-occurrence or segregation. If species abundance covary with environmental gradients, then the outcomes of competitive interactions may also vary with the environment (q.v. Cadotte and Tucker 2018). In this sense, differences in local habitat conditions alone are probably insufficient to explain the observed abundance differences between the two Chalceus species along the studied stretch in the Madeira River.

\section{Biological aspects and conservation issues}

The high proportion of single specimens of Chalceus in our samples (68\% for C. epakros and 52\% for C. guaporensis; data not shown) indicates that both species do not form large schools. Samples with more than 10 specimens were rare and observed only in the São Lourenço and Jaciparaná rivers for C. guaporensis during the lowing and dry periods (June to September), probably as a result of the seasonal contraction of aquatic habitats, leading to increased fish densities and capture rates with gillnets.

Regarding biological aspects, Chalceus guaporensis was inferred to spawn in the early flooding season as expected for most species of Characiformes inhabiting large rivers of the Amazon Basin (Lowe-McConnell 1987). Both C. guaporensis and C. epakros were considered allochthonous invertivores. Chalceus guaporensis fed predominantly on ants, crickets, spiders and butterfly larvae, while $C$. epakros consumed mostly termites, wasps and ants. The high consumption of allochthonous invertebrates can be considered typical of Chalceus species, as also shown by Röpke et al. (2014) for C. epakros occupying aquatic macrophyte stands in the lower Trombetas River. This suggests that food resource availability should not be an ecological restriction to C. epakros occurrence upstream from the Teotônio Fall, once riparian vegetation is abundant in the uppermost reaches of the Madeira River.

Species conservation may involve the protection or restoration of specific habitats, which in turn depends on identifying and preserving environmental elements such as rapids and falls. The hydroelectrical power plants of Jirau and Santo Antônio dammed the Madeira River recently (2011). Both run-of-river dams built in cascade flooded important geographical barriers (Jirau and Teotônio falls, respectively) and drowned a large portion of the lower courses of several tributaries of the upper Madeira River Basin (Torrente-Vilara et al. 2011). These environmental changes submerged a large stretch of rapids and substituted it by semi-lenthic habitats created by the dam reservoirs. This, together with the construction of a fish passage linking the floodplain of the lower Madeira River to the reservoir of Santo Antônio dam, may allow the invasion of the upper reaches of the Madeira River by C. epakros. Besides, this kind of anthropogenic disturbance may alter the co-occurrence pattern of the two Chalceus species in that portion of the river (e.g. Larsen and Ormerod 2014), with possible negative impacts for the endemic C. guaporensis. Attenuation of the local flood pulse by the dams, and possible disruption of the seasonal input of allochthonous materials to the river (such as fish food items) constitute a strong and (possibly) irreversible environmental impact. In this sense, a conservation plan for the endemic Chalceus guaporensis is necessary in order to protect its remaining habitats and life cycle. Unfortunately, a similar destiny may be foreseen for C. epakros in the lower Madeira River Basin. The Machado River, one of the main tributaries used by this species in the Madeira River Basin, is currently being impacted by the construction of another dam (Tabajara Hydroelectric Power Plant). Habitat conservation and natural biogeographical filters (e.g. falls) regulating species distribution are two fundamental conditions to the maintenance of the richest freshwater fish fauna in the world, but biodiversity conservation does not appear as a current priority in the Brazilian governmental planning (Ferreira et al. 2014). Effective actions for protecting floodplain areas throughout the Madeira River Basin (including its tributaries) are urgent and strongly needed to face the expected impacts of dams that are under construction or scheduled for construction in the Amazon (Finer and Jenkins 2012; Latrubesse et al. 2017).

\section{CONCLUSIONS}

Chalceus guaporensis is not restricted to its upper reaches as initially supposed and was detected downstream from the Santo Antônio Fall in the Madeira River. Despite the co-occurrence of both Chalceus species in the rapids stretch of the Madeira River, they were rarely collected together in 
the same sample, which suggests competitive interactions between the species. The higher abundance of $C$. guaporensis further suggests that this species could be best adapted to the habitats found at tributaries along the rapids stretch of the Madeira River.

\section{ACKNOWLEDGMENTS}

We are thankful to Santo Antônio Energia (SAE) and Universidade Federal de Rondônia (UNIR), Instituto de Estudos e Pesquisas Agroambientais e Organizaçôes Sustentáveis (IEPAGRO) and Instituto Nacional de Pesquisas da Amazônia (INPA), for financial and logistic support during the study. ACR received scholarships from Fundação de Amparo à Pesquisa do Estado do Amazonas (FAPEAM) and Conselho Nacional de Desenvolvimento Científico e Tecnológico (CNPq, processes 62.01947/2013 and 233358/2014-5, respectively). MH received a scholarship from Coordenação de Aperfeiçoamento de Pessoal de Nível Superior (CAPES, process 21/2012, Pro-Amazon Program: Biodiversity and Sustainability 047/2012). JZ receives a productivity grant from CNPq (process \#313183/2014-7). CPR received scholarships from CNPq and CAPES (processes 149428/2012-0 and BEX 3099/14-8, respectively). GTV and CRCD received a grant from CAPES (Pro-Amazon Program: Biodiversity and Sustainability 047/2012). GTV received a grant from Fundação de Amparo à Pesquisa do Estado de São Paulo (FAPESP, process 2016/07910-0). We also wish to thank Dr. Paula Jimenez for the English editing and proofreading and the anonymous reviewers for the valuable suggestions.

\section{REFERENCES}

Anderson, R.P.; Peterson, A.T.; Gómez-Laverde, M. 2002. Using niche-based GIS modeling to test geographic predictions of competitive exclusion and competitive release in South American pocket mice. Oikos, 98: 3-16.

Araújo-Lima, C.A.R.M.; Oliveira, E.C. 1998. Transport of larval fish in the Amazon. Journal of Fish Biology, 53: 297-306.

Brown, W.L.; Wilson, E.O. 1956. Character displacement. Systematic Zoology, 5: 49-64.

Cadotte, M.W.; Tucker, C.M. 2018. Should environmental filtering be abandoned? Trends in Ecology and Evolution, 32:429-437.

Capitán, J.A.; Cuenda, S.; Alonso, D. 2015. How similar can cooccuring species be in the presence of competition and ecological drift? Journal of the Royal Society Interface, 12: 1-9.

Cella-Ribeiro, A.; Torrente-Vilara, G.; Hungria, D.B.; Oliveira, M. 2013. As corredeiras do rio Madeira. In: Queiroz, L.J.; TorrenteVilara, G.; Ohara, W.M.; Pires, T.: Zuanon, J.A.S.; Doria, C.R.C. (Ed.). Peixes do rio Madeira. v.1.Dialeto, São Paulo, SP. p.56-63.

Cella-Ribeiro, A.; Hauser, M.; Nogueira, L.D.; Doria, C.R.C.; Torrente-Vilara, G. 2015. Length-weight relationships of fish from Madeira River, Brazilian Amazon, before the construction of hydropower plants. Journal of Applied Ichthyology, 31: 939-945.

Cella-Ribeiro, A.; Torrente-Vilara, G. ; Lima-Filho, J.; Doria, C.R.C. 2016. Ecologia e Biologia de Peixes do rio Madeira. EDUFRO, Porto Velho, 305p.

Dias, M.S.; Cornu, J.F.; Oberdorff, T.; Lasso, C.A.; Tedesco, P.A. 2013. Natural fragmentation in river networks as a driver of speciation for freshwater fishes. Ecography, 36: 683-689.

Davies, J.T.; Meiri, S.; Barraclough, T.G.; Gittleman, J.L. 2007. Species co-existence and character divergence across carnivores. Ecology Letters, 10: 146-152.

Duponchelle, F.; Lino, F.; Hubert, N.; Panfili, J.; Renno, J.F.; Baras, E., et al. 2007. Environment-related life-history trait variations of the red-bellied piranha Pygocentrus nattereri in two river basins of the Bolivian Amazon. Journal of Fish Biology, 71: 1113-1134.

Eschmeyer, W.N.; Fricke, R.;Van der Laan R. 2017. Catalog of genera, species, references. (http://researcharchive.calacademy. $\mathrm{org} /$ research/ichthyology/catalog/fishcatmain.asp.). Accessed on 23 Mar 2017.

Estevo, C.A.; Nagy-Reis, M.B.; Nichols, J.D. 2017. When habitat matters: Habitat preferences can modulate co-occurrence patterns of similar sympatric species. PLoS ONE, 12: e0179489.

Ferreira, J.; Aragão, L.E.O.C.; Barlow, J.; Barreto, P.; Berenguer, E.; Bustamante, M., et al. 2014. Brazil's environmental leadership at risk. Science, 346: 706-707.

Finer, M.; Jenkins, C.N. 2012. Proliferation of Hydroelectric Dams in the Andean Amazon and Implications for Andes-Amazon Connectivity. PLoS ONE, 7: e35126.

Godsoe, W.; Jankowsky, J.; Holt, R.D.; Gravel, D. 2017. Integrating biogeography with contemporary niche theory. Trends in Ecology and Evolution, 32: 488-499.

Gravena, W.; da Silva, V.M.F.; da Silva, M.N.F.; Farias, I.P.; Hrbek, T. 2015. Living between rapids: genetic structure and hybridization in botos (Cetacea: Iniidae: Inia spp.) of the Madeira River, Brazil. Biological Journal of the Linnean Society, 114: 764-777.

Hahn, N.S.; Loureiro, V.E.; Delariva, R.L. 1999. Atividade alimentar da curvina Plagioscion squamosissimus (Heckel, 1840) (Perciformes, Scianidae) no rio Paraná. Acta Scientiarum Biological Science, 21: 309-314.

Hart, S.P.; Usinowicz, J.; Levine, J.M. 2017. The spatial scales of species coexistence. Nature Ecology and Evolution, 1: 1066-1073.

Helmus, M.R.; Savage, K.; Diebel, M.W.; Maxted, J.T.; Ives, A.R. 2007. Separating the determinants of phylogenetic community structure. Ecology Letters, 10: 917-925.

Hrbek, T.; Vasconcelos, W.R.; Rebelo, G.; Farias, I.P. 2008. Phylogenetic Relationships of South American Alligatorids and the Caiman of Madeira River. Journal of Experimental Zoology, 309: 588-599.

Hutchinson, G.E. 1959. Homage to Santa Rosalia, or why are there so many kinds of animals? American Naturalist, 93: 245-249.

Hyslop, E.J. 1980. Stomach contents analysis - a review of methods and their application. Journal of Fish Biology, 17: 411-429. 
Junk, W.J.; Bayley, P.B.; Sparks, R.E. 1989. The flood pulse concept in river-floodplain systems. In: Dodge, D.P (Ed.). Proccedings of the International Large River Symposium (LARS). Canadian Special Publication of Fisheries and Aquatic Sciences, p.110-127

Kawakami, E.; Vazzoler, G. 1980. Método gráfico e estimativa de índice alimentar aplicado no estudo da alimentação de peixes. Boletim do Instituto Oceanográfico, 29: 205-207.

Larsen, S.; Ormerod, S. J. 2014. Anthropogenic modification disrupts species co-occurrence in stream invertebrates. Global Change Biology 20: 51-60.

Latrubesse, E.; Arima, E.Y.; Dunne, T.; Park, E.; Baker, V.R.; d'Horta, F.M. et. al. 2017. Damming the rivers of the Amazon basin. Nature, 546: 363-369.

Lowe-McConnell, R.H. 1987. Ecological studies in tropical fish communities. Cambridge University, Cambridge, 382p.

Mooney, K.A.; Jones, P.; A. Agrawal, A. 2008. Coexisting congeners: demography, competition, and interactions with cardenolides for two milkweed-feeding aphids. Oikos, 117: 450-458.

Núñez, J.; Duponchelle, F. 2009. Towards a universal scale to assess sexual maturation and related life history traits in oviparous teleost fishes. Fish Physiology and Biochemistry, 35: 167-180.

Oliveira, C.; Avelino, G.; Abe, K.; Mariguela, T.; Benine, R.; Orti, G., et al. 2011. Phylogenetic relationships within the speciose family Characidae (Teleostei: Ostariophysi: Characiformes) based on multilocus analysis and extensive ingroup sampling. BMC Evolutionary Biology, 11: 1-25.

Ovando, A.; Tomasella, J.; Rodriguez, D.A.; Martinez, J.M.; Siqueira-Junior, J.L.; Pinto, G.L.N., et al.2016. Extreme flood events in the Bolivian Amazon wetlands. Journal of Hydrology: Regional Studies, 5: 293-308.

Peterson, A.T. 1999. Conservatism of Ecological Niches in Evolutionary Time. Science, 285: 1265-1267.

Planquette, P.; Keith, P.; Le Bail, P. 1996. Atlas des poissons d' eau douce de Guyane. Muséum National d'Histoire Naturelle, Paris, 429p.

Queiroz, L.J.; Torrente-Vilara, G.; Ohara, W.M.; Pires, T.: Zuanon, J.A.S.; Doria, C.R.C. 2013. Peixes do rio Madeira, Dialeto, Sáo Paulo, SP

Queiroz, L.J.; Torrente-Vilara, G.; Quilodran, C.; Doria, C. R. C.; Montoya-Burgos, J.I. 2017. Multifactorial genetic divergence processes drive the onset of speciation in an Amazonian fish. PlosOne, 12: 1-27.

R CoreTeam. 2014. R: A language and environment for statistical computing. R Foundation for Statistical Computing, Vienna, Austria. http://www.R-project.org.

Röpke, C.P.; Ferreira, E.F.; Zuanon, J. 2014. Seasonal changes in the use of feeding resources by fish in stands of aquatic macrophytes in an Amazonian floodplain, Brazil. Environmental Biology of Fishes, 97: 401-414.

Santos, R.C.; Viana, M.N.S.; Montelejó, L.A.S.; Andrade, P.C.M.; Pantoja-Lima, J.; Oliveira, P.H.G.; Vogt, R.C.; Pezzuti, J.C.B.; Sites Jr., W.J.; Hrbek, T.; Farias, I.P. 2016. Testing the effects of barriers on the genetic connectivity in Podocnemis erythrocephala (red-headed Amazon River Turtle): implications for management and conservation. Chelonian Conservation and Biology, 15: 12-22.

Simóes, P.I.; Lima, A.P.; Magnusson, W.E.; Hödl, W.; Amézquita, A. 2008. Acoustic and morphological differentiation in the frog Allobates femoralis: relationships with the upper Madeira River and other potential geological barriers. Biotropica, 40: 607-614.

Simões, P.I.; Lima, A.P.; Farias, I.P. 2010. The description of a cryptic species related to the pan-Amazonian frog Allobates femoralis (Boulenger 1883) (Anura: Aromobatidae). Zootaxa, 2406: 1-28.

Simóes, P.I.; Lima, A.P.; Farias, I.P. 2012. Restricted natural hybridization between two species of litter frogs on a threatened landscape in southwestern Brazilian Amazonia. Conservation Genetics, 13: 1145-1159.

Sioli, H. 1968. Hydrochemistry and geology in the Brasilian Amazon region. Amazoniana, 1: 267-277.

Siqueira-Júnior, J.L.; Tomasella, J.; Rodriguez, D.A. 2015. Impacts of future climatic and land cover changes on the hydrological regime of the Madeira River basin. Climatic Change, 129: 117-129.

Thomas, C.D.; Kunin, W.E. 1999. The spatial structure of populations. Journal of Animal Ecology, 68: 647-657.

Tischendorf, L.; Fahrig, L. 2000. On the usage and measurement of landscape connectivity. Oikos, 90: 7-19.

Torrente-Vilara, G.; Zuanon, J.; Leprieur, F.; Oberdorff, T.; Tedesco, P.A. 2011. Effects of natural rapids and waterfalls on fish assemblage structure in the Madeira River (Amazon Basin). Ecology of Freshwater Fish, 20: 588-597.

Tremlová, K.; Münzbergová, Z. 2007. Importance of species traits for species distribution in fragmented landscapes. Ecology, 88: 965-977.

Venables, W. N.; Ripley, B. D. 2002. Modern Applied Statistics with S. Fourth Edition. Springer, New York. 495p.

Wickham, H. 2009. ggplot2: Elegant Graphics for Data Analysis. Springer-Verlag New York. 260p.

Zanata, A.M. 2013. Alestidae. In: Queiroz, L.J.; Torrente-Vilara, G.; Ohara, W.M.; Pires, T.; Zuanon, J.A.; Doria, C.R.C. (Ed.). Peixes do rio Madeira. v.2. Dialeto, São Paulo, p.48-51.

Zanata, A.M.; Toledo-Piza, M. 2004. Taxonomic revision of the South American fish genus Chalceus Cuvier (Teleostei: Ostariophysi: Characiformes) with the description of three new species. Zoological Journal of the Linnean Society, 140: 103-135.

Zuanon, J.; Ferreira, E.J.G. 2008. Feeding ecology of fishes in the Brazilian Amazon - A naturalistic approach. In: Cyrino, J.E.P; Bureau, D.P.; Kapoor, B.G. (Ed.) Feeding and digestive functions of fishes, Enfield: Science Publishers, p.1-34.

RECEIVED: $12 / 10 / 2017$

ACCEPTED: $10 / 05 / 2018$

ASSOCIATE EDITOR: Dilermando Lima / Helder Espírito Santo 